\title{
Penambahan Nukleotida pada Ransum Broiler yang Dipelihara pada Suhu Lingkungan Berbeda terhadap Performa Organ Imunitas
}

\author{
The Effect of Dietary Nucleotide on the Immune Organs Performance of Broiler Raised \\ Under Different Environmental Conditions
}

\author{
R. L. Hakim*, L. D. Mahfudz, dan R. Muryani \\ Fakultas Peternakan dan Pertanian, Universitas Diponegoro \\ *Corresponding Author : rakha.luqmanul@gmail.com
}

\begin{abstract}
This study was aimed to know the effects of dietary nucleotide on the immune organs performance of broiler chickens raised under different environmental conditions. The material used was unsexed 165 birds broiler chickens 15 days old with an average body weight of $462.20 \pm 9 \mathrm{~g}$ (CV 3.95\%), and nucleotide supplemen. The experiment was completely randomized design with factorial patern $3 \times 3$ and 5 repeats. The first factor is three different levels of dietary nucleotide $\mathrm{T}_{0}=0 \mathrm{~g} / \mathrm{kg}, \mathrm{T}_{1}=0.5 \mathrm{~g} / \mathrm{kg}$ and $\mathrm{T}_{2}=1 \mathrm{~g} / \mathrm{kg}$ of feed and the second factor is environmental conditions with $\mathrm{S}_{1}=32 \pm 1^{\circ} \mathrm{C}, \mathrm{S}_{2}=23 \pm 1^{\circ} \mathrm{C}$ and $\mathrm{S}_{3}=24-34^{\circ} \mathrm{C}$. The parameters observed were: relative weight of immune organs that is bursa fabricius, thymus and spleen. Data were analysis of variance to determine the effect of treatment at the level of 5\%. It will be followed by Duncan's test if there is real treatment effect. The results showed that there was no interaction of dietary nucleotide with raised under different environmental conditions $(\mathrm{P}>0.05)$ and fed dietary nucleotide. Comfortable environment signifficantly $(\mathrm{P}<0.05)$ improved relative weight of thymus, however hot environment reduced relative weight of thymus and bursa while enhanced relative weight of spleen. In conclusion, comfortable environment supported performance of immune organs, and hot environment inhibited performance of immune organs.
\end{abstract}

Key words : broiler chickens, nucleotide, immune organs, temperature

\begin{abstract}
ABSTRAK
Penelitian ini bertujuan untuk mengkaji performa organ imunitas akibat penambahan nukleotida pada ransum ayam broiler yang dipelihara pada kondisi suhu lingkungan yang berbeda. Materi yang digunakan yaitu 165 ekor ayam broiler unsexed berumur 15 hari dengan bobot rata-rata 462,20 $\pm \mathrm{g}$ (CV 3,95\%). Rancangan yang digunakan yaitu rancangan acak lengkap pola faktorial $3 \times 3$ dengan 5 ulangan. Faktor utama yaitu penambahan nukleotida, $\mathrm{T}_{0}=0 \mathrm{~g} / \mathrm{kg}$ pakan, $\mathrm{T}_{1}=0,5 \mathrm{~g} / \mathrm{kg}$ pakan dan $\mathrm{T}_{2}=1 \mathrm{~g} / \mathrm{kg}$ pakan, dan faktor kedua yaitu suhu lingkungan, $\mathrm{S}_{1}=32 \pm 1^{\circ} \mathrm{C}$, $\mathrm{S}_{2}=23 \pm 1^{\circ} \mathrm{C}$ dan $\mathrm{S}_{3}=24-34^{\circ} \mathrm{C}$. Parameter yang diamati berupa ukuran bobot relatif organ imunitas yaitu bursa fabricius, timus, dan limpa. Data yang diperoleh dianalisis ragam dengan uji $\mathrm{F}$ pada taraf $5 \%$ untuk mengetahui pengaruh perlakuan. Apabila terdapat pengaruh perlakuan yang nyata dilanjutkan dengan uji beda wilayah ganda Duncan. Hasil penelitian menunjukan tidak adanya $(\mathrm{P}>0,05)$ pengaruh interaksi antara suhu lingkungan dengan pemberian level nukleotida. Kondisi suhu lingkungan yang nyamaan berpengaruh nyata $(\mathrm{P}<0,05)$ meningkatnya bobot relatif timus, tetapi suhu lingkungan yang panas menurunkan bobot relatif timus dan bursa serta meningkatkan bobot relatif limpa. Simpulan dari penelitian ini adalah pemeliharaan pada suhu lingkungan nyaman mendukung performa organ imunitas dan suhu lingkungan panas menghambat performa organ imunitas.
\end{abstract}

Kata kunci : ayam broiler, nukleotida, organ imunitas, suhu lingkungan

\section{PENDAHULUAN}

Ayam broiler merupakan jenis ayam yang pertumbuhannya sangat cepat sehingga dapat dipanen pada umur 4-5 minggu. Metabolisme tubuh yang cepat menyebabkan peningkatan suhu tubuh menjadi mudah tinggi sehingga ayam relatif sensitif terhadap suhu lingkungan. Ayam broiler juga memiliki beberapa kelemahan diantaranya sulit beradaptasi terhadap lingkungan sehingga mudah stres dan mudah terserang penyakit akibat pengaruh lingkungan. Stres panas dapat menimbulkan dampak pada penurunan kesehatan dan produktivitas (Sugito et al., 2011 dan Nangoy, 2012).

Rata-rata suhu dan kelembaban yang ada di Indonesia berkisar antara $23-32^{\circ} \mathrm{C}$ dan $75-$ $80 \%$ (Nasrullah et al., 2017). Tingginya suhu dan kelembaban lingkungan akan menyebabkan ternak terkena cekaman panas yang mengakibatkan proses fisiologi dalam tubuhnya tidak sempurna dan mempengaruhi organ imunitas serta menurunkan produksi (Rotiah et al., 2018). 
Pada kondisi pertumbuhan yang cepat, stres maupun dalam keadaan sakit, hewan tidak mampu memenuhi kecukupan nukleotida di dalam tubuhnya sendiri secara endogenus melalui mekanisme de novo dan salvage pathway (Carver, 1999), sehingga perlu suplementasi nukleotida secara eksogenus. Kekurangan sintesis nukleotida berdampak pada perkembangan organ imunitas (bursa, timus dan limpa).

Nukleotida merupakan nutrien yang bersifat semi esensial yang dibutuhkan dalam proses pertumbuhan serta berperan dalam proses pembelahan sel organisme hidup termasuk performa organ imunitas (Kruger dan Werf, 2018). Nukleotida berperan dalam kontribusi terhadap metabolisme energi, peningkatan fagositas atau respons imunologis meliputi sistem kekebalan selular mapun humoral serta pembentukan atau perbanyakan sel baru (Safari et al., 2014; Hess dan Greenberg, 2012). Kekurangan nukleotida dalam tubuh dapat menyebabkan kerusakan pada sel kekebalan ayam tersebut (Silva et al., 2009). Sel-sel limfosit pada jaringan limfoid terus diproduksi maka ketersediaan nukleotida harus dipertahankan. Pada kondisi pertumbuhan yang cepat, stres maupun dalam keadaan sakit hewan tidak mampu memenuhi kecukupan nukleotida di dalam tubuhnya sendiri. Nukleotida berperan dalam pengaktifan limfosit, sebagai metabolisme energi dan prekusor sintesis asam nukleat. Peran tersebut juga membantu proliferasi sel limfosit. Penambahan nukleotida secara eksogenus dibutuhkan untuk mencukupi proliferasi limfosit agar optimum (Carver, 1999).

Organ imunitas pada ayam broiler berperan dalam sistem kekebalan tubuh terhadap benda asing atau antigen yang masuk (Hewajuli dan Dhamayanti, 2015). Bursa fabricius dan timus merupakan organ tubuh yang berperan dalam sistem imun di dalam unggas sedangkan limpa berperan dalam perombakan eritrosit tua dan sekresi antibodi (Hanum et al., 2017). Adanya kondisi stres atau paparan penyakit pada ayam dapat mempengaruhi ukuran organ imunitas tersebut. Ketika dalam kondisi stres panas, kebutuhan nukleotida di dalam tubuh meningkat (Hess dan Greenberg, 2012). Peningkatan tersebut digunakan untuk meredam stres panas yang dihasilkan tubuh. Stres panas akan mempengaruhi perubahan bobot organ imunitas sehingga daya tahan tubuhnya menurun (Kusnadi, 2009). Pemberian nukleotida dapat meningkatkan bobot relatif organ imunitas terutama bursa fabricius (Daneshmand et al., 2017). Meningkatnya bobot relatif bursa yang dipengaruhi Nucleotide-rich Yeast-extract menandakan baiknya kekebalan humoral karena banyaknya limfosit yang disintesis (Leung, 2019).

Tujuan penelitian untuk mengkaji pengaruh pemberian nukleotida dalam ransum ayam broiler pada kondisi pemeliharaan dengan suhu lingkungan yang berbeda terhadap performa organ imunitas. Manfaat dari penelitian ini adalah memberikan informasi tentang peran pemberian nukleotida dalam ransum ayam broiler pada pemeliharaan dengan kondisi suhu lingkungan yang berbeda terhadap performa organ imunitas. Hipotesis penelitian ini adalah pemberian nukleotida pada ransum ayam broiler yang dipelihara dengan kondisi suhu lingkungan berbeda akan berpengaruh positif terhadap performa organ imunitas.

\section{MATERI DAN METODE}

Materi yang digunakan dalam penelitian ini adalah ayam broiler unsexed strain Ross sebanyak 165 ekor yang berumur 15 hari dengan

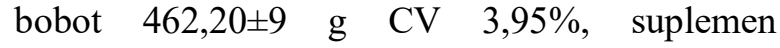
nukleotida. Pakan starter yang digunakan berupa B-11 dan bahan pakan basal untuk umur 15 hari dengan protein $18,9 \%$ dan EM $3100 \mathrm{kkal} / \mathrm{kg}$ disajikan pada Tabel 1.

Perlengkapan yang digunakan dalam penelitian berupa kandang dengan kondisi suhu panas $32 \pm 1^{\circ} \mathrm{C}$, suhu nyaman $23 \pm 1^{\circ} \mathrm{C}$ dan suhu alami $24-34^{\circ} \mathrm{C}$. Hasil temperatur masing-masing kondisi kandang dan kondisi heat stress indexnya disajikan pada Tabel 2. Tempat pakan dan minum, kipas angin hisap dari PT. Maspion, AC dari PT. Midea Electronic Indonesia, lampu bohlam 100 watt dari PT. Philip Indonesia Commercial serta timbangan analitik DS-22 dari Shenz Hanyu Electronic Tegy Co. Ltd., China.

Rancangan percobaan pola faktorial $3 \times 3$ dengan rancangan dasar acak lengkap yang terdiri dari 5 ulangan dan setiap unit percobaan diisi 3 ekor ayam. Faktor pertama adalah penambahan nukleotida $\left(\mathrm{T}_{0}=\right.$ Pakan kontrol, $\mathrm{T}_{1}=$ Pakan dengan penambahan nukleotida $0,5 \mathrm{~g} / \mathrm{kg}$ pakan, $\mathrm{T}_{2}=$ Pakan dengan penambahan nukleotida $1 \mathrm{~g} / \mathrm{kg}$ pakan). Faktor kedua adalah temperatur kandang $\left(\mathrm{S}_{1}=32 \pm 1^{\circ} \mathrm{C}, \mathrm{S}_{2}=23 \pm 1^{\circ} \mathrm{C}, \mathrm{S}_{3}=24^{\circ}-34^{\circ} \mathrm{C}\right)$. Diatur dengan penggunaan air condition untuk $\mathrm{S}_{2}$ dan lampu bohlamp untuk $\mathrm{S}_{1}$. 
Tabel 1. Komposisi dan kandungan nutrien pakan basal

\begin{tabular}{lr} 
Bahan Pakan & Kandungan (\%) \\
\hline Jagung & 62,00 \\
Bungkil kedelai & 26,50 \\
Dedak padi & 4,00 \\
Meat bone meal & 3,66 \\
DL-Metionin & 0,09 \\
Limestone Rough & 0,25 \\
Premix & 0,30 \\
NaCl & 0,20 \\
Minyak kelapa sawit & 3,00 \\
\hline Total & 100,00 \\
\hline Analisis Nutrien & 18,90 \\
Protein kasar & $3.145,50$ \\
ME (kkal/kg) & 0,76 \\
Ca & 0,32 \\
P & 0,38 \\
Metionin & 0,98 \\
Lisin & Paboratorium Ilmu Nutrisi dan Pakan Fakultas \\
\multicolumn{2}{c}{ Peternakan dan Pertanian Universitas } \\
\multicolumn{2}{c}{ Diponegoro, Semarang. }
\end{tabular}

Parameter yang di amati yaitu: ukuran bobot relatif organ imunitas seperti bursa fabricius, timus, dan limpa. Parameter tersebut diukur dengan cara membandingkan bobot absolut organ dengan bobot ternak.

Tabel 2. Kondisi suhu lingkungan dan heat stress index

\begin{tabular}{|c|c|c|c|}
\hline & Panas & Nyaman & Alami \\
\hline Suhu $\left({ }^{\circ} \mathrm{C}\right)$ & $32 \pm 1$ & $23 \pm 1$ & $24-34$ \\
\hline Kelembaban \% & 65 & 64 & $50-70$ \\
\hline Heat stress index & 154,6 & 137,4 & 144,2 \\
\hline
\end{tabular}

Tahap persiapan dimulai dengan persiapan kandang dan perlengkapannya. Persiapan kandang dilakukan dengan cara pembersihan kandang, pengapuran, pemasangan lampu, kipas dan AC serta fumigasi kandang dengan formalin dan $\mathrm{KMNO}_{4}$ Tiga ekor ayam diletakkan pada kandang yang telah disekat dengan ukuran 40 x $50 \mathrm{~cm}$ untuk kondisi lingkungan panas dan nyaman yang dilengkapi dengan tempat pakan dan tempat minum. Sedangkan untuk kondisi lingkungan alami, 5 ekor ayam diletakkan pada kandang dengan ukuran 1 x $1 \mathrm{~m}$ yang dilengkapi dengan tempat pakan dan minum. Alas untuk setiap kandang berupa alas litter sekam. Pembelian nukleotida BioNutrend ${ }^{\circledR}$ yang diproduksi oleh CBH Co. Ltd., China. Kandungannya terdiri dari AMP, GMP, CMP dan UMP; dan di ekstrak dari yeast (Saccharomyces cereviase)

Pengambilan data dilakukan dengan cara mengambil sampel sebanyak satu ekor ayam umur 35 hari dari masing-masing unit percobaan. Ayam dipuasakan selama 12 jam sebelum dipotong, pengambilan organ imunitas (bursa fabricius, timus dan limpa) dengan pisau bedah, gunting bedah dan pinset. Organ imunitas yang telah diambil kemudian dibersihkan dengan larutan $\mathrm{NaCl}$ fisiologis dan ditimbang dengan timbangan analitik DS-22 untuk dicari bobot organ imunitas (bursa fabricius, timus dan limpa).

1. Bursa fabricius

Bobot organ bursa fabricius yaitu dengan penimbangan organ bursa fabricius yang telah dibersihkan dari darah yang menempel (Elisa et al., 2017).

2. Timus

Bobot organ timus yaitu dengan penimbangan organ timus yang telah dibersihkan dari lemak yang menempel, jumlah organ timus yang terdapat pada ayam dan bobot rata-rata organ timus (Elisa et al., 2017).

3. Limpa

Bobot organ limpa yaitu dengan penimbangan organ limpa yang telah dibersihkan dari darah yang menempel. Bobot organ yang telah diperoleh kemudian di cari bobot relatifnya. Bobot relatif organ imunitas dihitung dengan rumus:

Bobot Relatif $(\%)=\frac{\text { Bobot Organ }}{\text { Bobot Hidup }} \times 100 \%$

(Aprillia et al., 2018)

\section{Analisis data}

Model linier yang menjelaskan nilai setiap pengamatan untuk percobaan faktorial dengan RAL adalah :

$$
\mathrm{Y}_{\mathrm{ijk}}=\mu+\alpha_{\mathrm{i}}+\beta_{\mathrm{j}}+(\alpha \beta)_{\mathrm{ij}}+\varepsilon_{\mathrm{ijk}}
$$

Keterangan :

$\mathrm{Y}_{\mathrm{ijk}}=$ Hasil pengamatan pada ulangan ke-k yang mendapat perlakuan penambahan nukleotida ke-i dan kondisi pemeliharaan ayam ke-j

$\mu \quad=$ Nilai rata-rata umum

$\alpha_{\mathrm{i}} \quad=$ Pengaruh perlakuan penambahan nukleotida ke-I

$\beta_{\mathrm{j}} \quad=$ Pengaruh kondisi pemeliharaan ayam ke-j 
$(\alpha \beta)_{\mathrm{ij}}=$ Pengaruh interaksi perlakuan penambahan nukleotida ke-i dan kondisi pemeliharaan ayam ke-j

$\varepsilon_{\mathrm{ijk}}=$ Galat percobaan akibat perlakuan penambahan nukleotida, kondisi pemeliharaan ayam ke-j dan ulangan ke-k.

Data yang diperoleh dianalisis menggunakan analisis ragam dengan uji $\mathrm{F}$ pada taraf 5\% untuk mengetahui pengaruh perlakuan. Apabila terdapat pengaruh perlakuan yang nyata akan dilanjutkan dengan uji beda wilayah ganda Duncan (Sudarwati et al., 2019). Data dianalisis dengan bantuan aplikasi software SAS 9.1 (Statiscal Analysis System).

\section{HASIL DAN PEMBAHASAN}

\section{Bursa Fabricius}

Hasil pengaruh perlakuan penambahan nukleotida pada ransum ayam broiler yang dipelihara pada suhu lingkungan yang berbeda disajikan pada Tabel 3. Analisis statistik menunjukkan tidak berpengaruh nyata $(\mathrm{P}>0,05)$ interaksi pengaruh perlakuan antara penambahan nukleotida dan pemeliharaan pada kondisi suhu lingkungan yang berbeda terhadap bobot relatif organ bursa fabricius. Pemeliharaan pada kondisi suhu lingkungan yang berbeda juga menunjukan tidak ada pengaruh nyata $(\mathrm{P}>0,05)$ terhadap bobot relatif bursa fabricius.

Tabel 3. Rataan bobot relatif organ imunitas ayam broiler

\begin{tabular}{|c|c|c|c|c|}
\hline \multirow{2}{*}{ Perlakuan } & & \multicolumn{3}{|c|}{ Variabel } \\
\hline & & Bursa Fabricius (\%) & Timus $(\%)$ & Limpa (\%) \\
\hline \multirow{3}{*}{$\begin{array}{l}\text { Panas } \\
\left(\mathrm{S}_{1}\right)\end{array}$} & $\mathrm{T}_{0}$ & 0,048 & 0,116 & 0,077 \\
\hline & $\mathrm{T}_{1}$ & 0,050 & 0,143 & 0,076 \\
\hline & $\mathrm{T}_{2}$ & 0,038 & 0,118 & 0,080 \\
\hline \multirow{3}{*}{$\begin{array}{l}\text { Nyaman } \\
\left(\mathrm{S}_{2}\right)\end{array}$} & $\mathrm{T}_{0}$ & 0,049 & 0,197 & 0,077 \\
\hline & $\mathrm{T}_{1}$ & 0,048 & 0,160 & 0,075 \\
\hline & $\mathrm{T}_{2}$ & 0,049 & 0,191 & 0,095 \\
\hline \multirow{3}{*}{$\begin{array}{l}\text { Alami } \\
\left(\mathrm{S}_{3}\right)\end{array}$} & $\mathrm{T}_{0}$ & 0,036 & 0,130 & 0,208 \\
\hline & $\mathrm{T}_{1}$ & 0,044 & 0,090 & 0,186 \\
\hline & $\mathrm{T}_{2}$ & 0,047 & 0,142 & 0,265 \\
\hline \multirow{3}{*}{$\begin{array}{l}\text { Kondisi } \\
\text { Lingkungan }\end{array}$} & Panas & 0,045 & $0,125^{b}$ & $0,078^{b}$ \\
\hline & Nyaman & 0,048 & $0,182^{\mathrm{a}}$ & $0,082^{b}$ \\
\hline & Alami & 0,042 & $0,120^{\mathrm{b}}$ & $0,219^{\mathrm{a}}$ \\
\hline Penambahan & $\mathrm{T}_{0}$ & 0,044 & 0,147 & 0,121 \\
\hline \multirow{2}{*}{ Nukleotida } & $\mathrm{T}_{1}$ & 0,047 & 0,130 & 0,112 \\
\hline & $\mathrm{T}_{2}$ & 0,044 & 0,150 & 0,146 \\
\hline \multirow[t]{3}{*}{ Probabilitas } & Ling $\times \mathrm{Nt}$ & 0,39 & 0,08 & 0,58 \\
\hline & Lingkungan & 0,44 & 0,00 & 0,00 \\
\hline & Nukleotida & 0,73 & 0,24 & 0,20 \\
\hline
\end{tabular}

Berdasarkan Tabel 3, analisis statistik menunjukan tidak adanya pengaruh perlakuan penambahan nukleotida terhadap bobot relatif organ imunitas. Hal ini terjadi karena suplai nukleotida ke organ Bursa Fabricius tidak terlalu banyak disebabkan oleh berbagai hal yaitu kapasitas penyerapan, sistem transportasi ke organ imunitas dan kebutuhan nukleotida pada organ lainnya. Menurut Carver (1999), 2 - 5\% suplemen nukleotida berada pada usus halus, hati dan jaringan otot. Silva et al. (2009) menambahkan bahwa kebutuhan nukleotida dapat dipengaruhi oleh beberapa faktor diantaranya pertumbuhan yang cepat, ternak dalam kondisi sakit, kondisi suhu dan lingkungan serta kekurangan nutrien pakan.
Rata-rata bobot relatif bursa yaitu 0,036 $0,050 \%$, hasil ini lebih rendah dari penelitian Leung et al. (2019) yang melaporkan bahwa bobot rata-rata bursa sebesar $0,144-0,174 \%$. Bursa fabricius merupakan organ penting dalam merespon pertahanan tubuh, organ ini berperan sebagai differensiasi limfosit B. Kondisi stres dapat memacu kerja organ ini sehingga terjadi deplesi. Cekaman panas mengakibatkan ayam stres yang dapat merangsang pengeluaran hormon kortikosteron. Menurut Tamzil (2014), hormon kortikosteron dapat mengganggu fungsi sistem kekebalan tubuh dan jaringan limfoid. Kusnadi (2009) juga melaporkan bahwa peningkatan hormon kortikosteron akan merangsang perombakan protein menjadi glukosa 
sehingga terjadi penurunan bobot.

Bobot relatif bursa fabricius tidak berbeda

nyata antar perlakuan baik penambahan nukleotida maupun pemeliharaan pada suhu lingkungan yang berbeda. Hal ini dapat disebabkan perkembangan bobot bursa fabricius semakin lambat. Bobot yang rendah ini juga dapat dipengaruhi oleh kondisi pemeliharaan, jenis ayam dan umur. Menurut Puspitasari et al. (2016), bobot bursa fabricius dipengaruhi oleh kondisi ayam, tipe dan galur dari ayam tersebut. Kusnadi (2009) juga menambahkan bahwa ayam yang dipelihara pada kondisi stres seperti peningkatan suhu ruang dan kepadatan kandang yang tinggi mampu menurunkan bobot relatif bursa fabricius.

\section{Timus}

Berdasarkan Tabel 3, menunjukan bahwa tidak ada pengaruh interaksi $(\mathrm{P}>0,05)$ antara pemberian nukleotida dengan pemeliharaan pada suhu lingkungan yang berbeda. Hasil pengaruh perlakuan akibat dari penambahan nukleotida terhadap bobot relatif timus juga menunjukan tidak berpengaruh nyata $(\mathrm{P}>0,05)$.

Rata-rata bobot relatif timus berkisar antara $0,090-0,197 \%$, hasil tersebut lebih rendah dari penlitian Leung et al. (2019) yang berkisar $0,203-0,226 \%$. Hal ini dapat terjadi dikarenakan suplai nukleotida ke organ timus tidak dapat tercukupi. Nukleotida di dalam tubuh secara endogenus didapat sintesis melalui de novo dan salvage pathway.. Nukleotida di dalam tubuh secara endogenus tidak dapat tercukupi dikarenakan kondisi tertentu seperti kondisi stres dan proses penyembuhan. Menurut Hess dan Greenberg (2012), pada kondisi normal secara endogenus kebutuhan nukleotida tercukupi, namun pada kondisi stres kebutuhan nukleotida meningkat.

Pemeliharaan pada kondisi suhu lingkungan yang berbeda menunjukan hasil yang berpengaruh nyata $(\mathrm{P}<0,05)$ yaitu bobot relatif organ timus lebih besar pada kondisi suhu nyaman $\left(\mathrm{S}_{2}\right)$. Ayam yang dipelihara pada kondisi suhu nyaman memiliki bobot relatif yang lebih tinggi dikarenakan kondisi lingkungan yang mendukung sehingga performa pertumbuhan ayam baik. Perkembangan bobot relatif timus sejalan dengan perkembangan sel limfosit T. Menurut Gao et al. (2017), yang berpendapat bahwa berat timus diasumsikan dengan banyaknya sel limfosit $\mathrm{T}$. Peran limfosit $\mathrm{T}$ yaitu menyerang antigen yang masuk secara langsung melalui sel efektor maupun dengan mensekresikan sel memori ( $\mathrm{T}$ Helper) yang akan menstimulasi sel B untuk menghasilkan antibodi. Menurut Hewajuli dan Dhamayanti (2015), limfosit $\mathrm{T}$ berfungsi sebagai pengatur sintesis antibodi, sel efektor dan sel sitotoksik akan bereaksi secara spesifik dengan antigen. Leeson dan Summer (2000) juga menambahkan sel $\mathrm{T}$ pada timus akan mensekresikan sel reseptor yang secara langsung akan menyerang antigen yang masuk untuk menanggulangi infeksi.

Bobot relatif organ timus pada kondisi suhu panas $\left(S_{1}\right)$ dan alami $\left(S_{3}\right)$ tidak berbeda nyata. Pada kondisi suhu panas $\left(\mathrm{S}_{1}\right)$, pertumbuhan ayam sedikit terhambat sedangkan pada kondisi suhu alami $\left(\mathrm{S}_{3}\right)$, ayam dipelihara di ruanganan yang tidak tertutup seperti dalam kondisi suhu panas dan nyaman. Pada kondisi ini, lingkungan agak terbuka dengan mikroklimat sehingga dapat diasumsikan benda asing masuk ke dalam tubuh ayam. Niu et al. (2009) melaporkan bahwa bobot organ timus akan menurun sejalan dengan kondisi ternak yang terkena cekaman panas. Adanya paparan penyakit yang disebabkan kondisi udara terbuka juga dapat mempengaruhi bobot organ timus. Zulfa (2019) juga menambahkan bahwa baik buruknya kondisi sistem imun dilihat dari performa organ imunitas yang menandakan masuknya benda asing ke dalam tubuh.

\section{Limpa}

Berdasarkan Tabel 3, hasil analisis ragam menunjukan tidak adanya interaksi $(\mathrm{P}>0,05)$ pengaruh perlakuan antara penambahan nukleotida dan pemeliharaan pada kondisi lingkungan yang berbeda terhadap bobot organ limpa. Hasil perlakuan penambahan nukleotida terhadap bobot relatif limpa menunjukan tidak berpengaruh nyata $(\mathrm{P}>0,05)$. Hal ini dapat disebabkan karena suplai nukleotida menuju limpa tidak tercukupi. Carver (1999) menyatakan bahwa $2-5 \%$ suplemen nukleotida diedarkan pada saluran pencernaan seperti usus halus.

Rata-rata bobot relatif organ limpa yaitu sebesar $0,075-0,265 \%$. Leung et al (2019) melaporkan bahwa rata-rata bobot relatif organ limpa yaitu 0,094 - 0,096\%. Pemeliharaan pada suhu lingkungan yang berbeda memberikan hasil pengaruh yang nyata $(\mathrm{P}<0,05)$ terhadap bobot limpa. Pada suhu alami $\left(\mathrm{S}_{3}\right)$, bobot limpa lebih besar karena kondisi lingkungan yang terbuka. Hal ini dapat menyebabkan potensi masuknya benda asing di dalam tubuh lebih besar dan mudah terkena cekaman panas. Selain itu, bobot timus pada pemeliharaan suhu alami tidak terlalu besar sehingga kerja limpa menjadi lebih ekstra. 
Menurut Aprillia et al. (2018), limpa yang terkena serangan benda asing persentase bobotnya lebih besar. Zulfa et al. (2019) menambahkan bahwa pertumbuhan bobot organ limpa akan terganggu jika ternak terkena cekaman panas atau infeksi benda asing. Bobot relatif limpa pada pemeliharaan suhu panas $\left(\mathrm{S}_{1}\right)$ tidak berbeda nyata pada suhu nyaman $\left(\mathrm{S}_{2}\right)$.

Bobot limpa yang besar diasumsikan oleh banyaknya sel-sel limfosit yang berproliferisasi untuk mengeluarkan antibodi akibat banyaknya benda asing yang masuk. Bobot relatif limpa juga dipengaruhi oleh aktivitas organ tersebut. Aktivitas yang meningkat menyebabkan perkembangan yang meningkat juga, namun pada ayam yang sakit bobot limpa cenderung menurun. Rotiah et al. (2018) berpendapat bahwa bobot limpa dipengaruhi oleh aktivitas dari organ tersebut dan kesehatan ayam. Pada kondisi suhu panas $\left(S_{1}\right)$ dan nyaman $\left(S_{3}\right)$, bobot relatif limpa tidak berbeda nyata serta bobot timus lebih besar dari pemeliharaan suhu panas dan suhu alami. Hal ini menyebabkan kinerja organ limpa untuk menghasilkan limfosit $\mathrm{T}$ tidak terlalu berat dikarenakan bobot timus yang lebih besar. Limpa merupakan organ limfoid yang berperan dalam pematangan sel limfosit dan penghasil antibodi. Menurut Hewajuli dan Dharmayanti (2015), limpa sebagai tempat pendewasaan sel limfosit juga berperan dalam proses seleksi limfosit yang terpapar antigen untuk merespon keadaan antigen.

\section{KESIMPULAN}

Simpulan dari penelitian ini adalah pemeliharaan pada suhu lingkungan nyaman mendukung performa organ imunitas dan suhu lingkungan panas menghambat performa organ imunitas.

\section{DAFTAR PUSTAKA}

Carver, J. 1999. Dietary nucleotides: Effects on the immune and gastrointestinal systems. Acta Paediatrica (88) : 83-88.

Chiofalo, B., V. L. Presti, G. Savoini, E. D'Alessandro, V. Chiofalo dan L. Liotta. 2011. Nucleotides in broiler chicken diet: effect on breast muscles quality. Czech J. Food Sci. 29 (4): 308 - 317.

Daneshmand, A., H. Kermanshasi, M. D. Mesgaran, A. J. King dan S. A. Ibrahim. 2017. Combination of purine and pyrimidine nucleosides influences growth performance, gut morphology, digestive enzymes, serum biochemical indices and immune functions in broiler chickens. Animal Feed Science and Technology. 228: $186-193$.

Elisa, W., E. Widiastuti dan T. A. Sarjana. 2017. Bobot relatif organ limfoid dan usus halus ayam broiler yang disuplementasi probiotik bacilus plus. 2017. Prosiding Seminar Teknologi dan Agribisnis Peternakan V : Teknologi dan Agribisnis Peternakan untuk Mendukung Ketahanan Pangan, Fakultas Peternakan Universitas Jenderal Soedirman 18 November 2017. 297 - 301.

Gao, T., M. M. Zhao, L. Zhang, J. L. Li, L. L. Yu, P. A. Lv, F. Gao, dan G. H. Zhou. 2017. Effects of in ovo feeding of 1-arginine on the development of lymphoid organs and small instestinal immune barrier function in posthacth broilers. Animal Feed Science and Technology. DOI: http://dx.doi.org/10.1016/j.anifeedsci.2017. 01.004

Hanum, S., H. Budiman dan D. Masyhita. 2017. Gambaran histologis limpa ayam kampung (Gallus gallus domesticus) pada umur berbeda. J. Ilmiah Mahasiswa Veteriner 1 (3): $552-557$.

Hess., J. R. dan N. A. Greenberg. 2012. The role of nucleotides in the immune and gastrointestinal systems: potential clinical applications. Nutrition in Clinical Practice 27(2): $281-294$.

Hewajuli, D. A. dan N. L. P. I. Dhamayanti. 2015. Peran sistem kekebalan non-spesifik dan spesifik pada unggas terhadap newcastle disease. Wartazoa 25 (3): 135 - 146.

Jung, B. dan A. B. Batal. 2012. Effect of dietary nucleotide supplementation on performance and development of the gastrointestinal tract of broilers. Br. Poult. Sci. (53): $98-$ 105.

Kruger, D. dan M. V. D. Werf. 2018. Benefits of nucleotide supplementation in poultry. Ohly Application Note. 1 - 3 .

Kusnadi, E. 2009. Perubahan malonaldehida hati, bobot relatif bursa fabricius dan rasio heterofil/limfosit (h/l) ayam broiler yang diberi cekaman panas. Media Peternakan 32 (2): $81-87$. 
Leeson, S. dan J. D. Summer. 2000. Broiler Breeder Production. Nottingham University Press.

Leung, H., R. Patterson., J. R. Barta., N. Karrow dan E. Kiarie. 2019. Nucleotide-rich yeast extract fed to broiler chickens challenged with eimeria: impact on growth performance, jejunal histomorphology, immune system and apparent retention of dietary components and caloric efficiency. Poultry Science (0): $1-9$. DOI: https://dx.doi.org/10.3382/ps/pez213

Nangoy, F. J. 2012. Kajian penyusutan berat badan dan peningkatan suhu tubuh ayam broiler terimplementasi kurkuma (Curcuma longa) gula aren (Arenga pinata) akibat lama transportasi. Indonesian Journal of Applied Sciences 2 (3): 119 - 122.

Nasrullah., R. Rahim., Baharuddin., R, Mulyadi., N. Jamala dan A. Kusno. 2017. Temperatur dan kelembaban relatif udara outdoor. Di dalam Prosiding Temu Ilmiah IPLBI 2015.hal $45-50$.

Niu, Z. Y., F. Z. Liu, Q. L. Yan dan W. C. Li. 2009. Effect of different level of vitamin e on growth performance and immune responses of broiler under heat stress. Poultry Science 88 (10): 2101 - 2107.

Puspitasari, S., Isroli dan E. Kusumanti. 2016. Pengaruh penggunaan rumput laut dan pare dalam ransum terhadap jumlah leukosit dan persentase bobot bursa fabricius ayam broiler. J. Pengembangan Penyuluhan Pertanian 13 (23): 13 - 19.

Rotiah, E. Widiastuti dan D. Sunarti. 2018. Relative weight of small intestine and lymphoid organ of finisher period broiler chicken at different rearing temperatures. J. Animal Research and Applied Science 1 (1): $6-10$.

Safari, O., D. Shahsavani, M. Paolucci, and M. M. S. Atash. 2014. The effects of dietary nucleotide content on the growth performance, digestibility and immune responses of juvenile narrow clawed crayfish, A stacus leptodactylus leptodactylus Eschscholtz, 1823. Aquaculture Research 1(13): 2685-2697.

Silva, V. K., J. D. T. da Silva, K. A. A. Torres, D. E. de F. Filho, F. H. Hada dan V. M. B. de Moraes. 2009. Humoral immune response of broilers fed diets containing yeast extract and prebiotics in the prestarter phase and raised at different temperatures. J. Applied Poultry Research 18 (3): 530 - 540.

Sudarwati, H., M. H. Natsir dan V. M. A. Nurgiartiningsih. 2019. Statistika dan Rancangan Percobaan (Penerapan dalam Bidang Peternakan). UB Press.

Sugito, Fakhrurrazi dan M. Isa. 2011. Efek pemberian ekstrak jaloh dikombinasi dengan probiotik dan kromium terhadap profil hematologi dan titer antibodi vaksin ND pada ayam broiler yang mengalami stres panas. J. Agripet. 11 (2): $8-15$.

Tamzil, M. H. 2014. Stres Panas pada Unggas : Metabolisme, Akibat dan Upaya Penanggulangannya. Wartazoa 24 (2): 57 66.

Yasa, I M. S., I K. Darminta dan I K. Ta. 2019. Kontrol heat stress index ruangan ayam broiler pada periomode brooding secara otomatis berbasis arduino-uno. Politeknologi 18 (2): 151 - 158.

Zulfa, R., H. I. Wahyuni dan Sugiharto. 2019. Bobot relatif organ limfoid ayam broiler yang diberi ekstrak tomat sebagai air minum dan diinfeksi bakteri Escherichia coli. Seminar Nasional Dalam Rangka Dies Natalis UNS ke 43 Tahun 2019 : Sumber Daya Pertanian Berkelanjutan dalam Mendukung Ketahanan dan Keamanan Pangan Indonesia pada Era Revolusi Industri 4.0. hal $42-48$. 